\title{
Tropical upper tropospheric humidity variations due to potential vorticity intrusions
}

\author{
M. Sandhya ${ }^{1,2}$, S. Sridharan ${ }^{1}$, and M. Indira Devi ${ }^{2}$ \\ ${ }^{1}$ National Atmospheric Research Laboratory, Gadanki 517112, Pakala Mandal, Chittoor District, Andhra Pradesh, India \\ ${ }^{2}$ Department of Physics, Andhra University, Visakhapatnam 530003, Andhra Pradesh, India \\ Correspondence to: S. Sridharan (susridharan@narl.gov.in)
}

Received: 25 March 2015 - Revised: 7 July 2015 - Accepted: 27 August 2015 - Published: 3 September 2015

\begin{abstract}
Four cases (March 2009, May 2009, April 2010 and February 2012) are presented in which the ERA-interim relative humidity $(\mathrm{RH})$ shows consistent increase by more than $50 \%$ in the upper troposphere $(200-250 \mathrm{hPa})$ over tropics at the eastward side of the potential vorticity (PV) intrusion region. The increase in RH is confirmed with the spaceborne microwave limb sounder observations and radiosonde observations over Gadanki $\left(13.5^{\circ} \mathrm{N}, 79.2^{\circ} \mathrm{E}\right)$ and is observed irrespective of whether the $\mathrm{PV}$ intrusions are accompanied by deep convection or not. It is demonstrated that the increase in RH is due to poleward advection induced by the PV intrusions in their eastward side at the upper tropospheric heights. It is suggested that the low-latitude convection, which is not necessarily triggered by the PV intrusion, might have transported water vapour to the upper tropospheric heights.
\end{abstract}

Keywords. Meteorology and atmospheric dynamics (convective processes; tropical meteorology)

\section{Introduction}

Upper tropospheric water vapour is an important greenhouse gas and can influence surface radiative forcing (Jones and Mitchell, 1991; Udelhofen and Hartmann, 1995). Its variations have important climate implications (Hansen et al., 1984; Lindzen, 1990) and even minute variations can lead to greenhouse effect comparable to the large variations in the lower troposphere (Shine and Sinha, 1991). Radiative transfer model estimations show that a $10 \%$ increase in upper tropospheric humidity could contribute nearly $1.4 \mathrm{~W} \mathrm{~m}^{-2}$ of direct radiative forcing (Udelhofen and Hartman, 1995). Its radiative effects are significant in determining the energy budget of the Earth's climate system and the overall climate sensitivity to the build-up of anthropogenic greenhouse gases. However, this is one of the least well-measured parameters and significant uncertainties in the measurements remain a barrier to making reliable prediction about future climate change. In the past, satellite measurements, namely, the Stratospheric Aerosol and Gas Experiment, the Television Infrared Observation Satellite (TIROS), operational vertical sounder, $6.7 \mu \mathrm{m}$ brightness temperature from a single Geostationary Operational Environmental Satellite, Microwave Limb Sounder, and Atmospheric Infrared Sounder (AIRS) have contributed significantly to the retrieval of water vapour in the upper troposphere from the radiances and also to the understanding of its variabilities (Rind et al., 1993; Soden and Bretherton, 1993; Soden and Fu, 1995; Liao and Rind, 1997; Gettelman et al., 2006). These humidity observations from satellites are important data sources for humidity assimilation in global data assimilation systems (Chen et al., 1999). Rind et al. (1991) and Inamdar and Ramanathan (1994) observed enhanced upper tropospheric relative humidity (UTRH) associated with deep convection. Relation between UTRH and convection has been reported in various studies (Arakawa and Schubert, 1974; Newell and GouldStewart, 1981; Danielsen, 1982; Panwar et al., 2012 etc. to state a few). Deep convection over tropics can be triggered by potential vorticity (PV) intrusions (Waugh and Polvani, 2000).

Rossby wave breaking at mid-latitudes leads to transport of stratospheric air with high $\mathrm{PV}$ in to tropical upper troposphere (De Bellevue et al., 2006). These PV intrusions can be identified from relatively high PV value (>2 PVU) at $350 \mathrm{~K}$ isentropic level ( $\sim 200 \mathrm{hPa}$ over tropics) (Waugh and Polvani, 2000). They are more frequent over the Eastern Pacific and Atlantic sector during the northern winter 
whenever upper tropospheric westerlies are strong (Waugh and Polvani, 2000). They can trigger convection as a result of decreased stability and enhanced vertical motion and induce poleward advection (Kiladis, 1998; Funatsu and Waugh, 2008) ahead of the trough (eastward side). Though the number of PV intrusion events is less over the Indian sector, a recent study shows that it plays a major role in determining the spatial and temporal extents of pre-monsoon rainfall (Sandhya and Sridharan, 2014). During intrusion the transport of the stratospheric air which enters deep into the troposphere can modify the outgoing radiance (Kentarchos et al., 1998). The PV intrusions can influence the distribution of minor constituents. Folkins and Appenzeller (1996) and Baray et al. (1998) observed sudden changes in ozone mixing ratio at tropical latitudes in connection with the PV intrusion. Ryoo et al. (2008) studied the variability of subtropical UTRH during the northern winter and reported that both convection and poleward advection during PV intrusions could contribute towards increase in UTRH. However, we present four cases here, in which even tropical UTRH variations are shown to be dependent on the northward advection associated with the PV intrusions irrespective of whether the intrusions are accompanied by deep convection or not. The paper is organised as follows. In Sect. 2, the different data sets used are described and the results are presented in Sect. 3. A detailed discussion and conclusion are provided in Sect. 4.

\section{Data sets}

\subsection{ERA-interim data sets}

European Centre for Medium Range Weather Forecasting (ECMWF) reanalysis (ERA) interim data sets are results from analysis conducted at 6-h intervals available for latitude-longitude grids $3^{\circ} \times 3^{\circ}-0.125^{\circ} \times 0.125^{\circ}$ and are prepared by ECMWF using their variational data assimilation system (Berrisford et al., 2009). However we have used all data sets with gird size $1.5^{\circ} \times 1.5^{\circ}$ for the present study. These data sets are currently available in the website http://apps.ecmwf.int/datasets/data/interim-full-daily/ for 15 isentropic levels and 37 pressure levels. In the present study, potential vorticity and RH at different pressure levels are used. The $350 \mathrm{~K}$ isentropic level has traditionally been used to identify the occurrence of PV intrusions into the tropical troposphere (Waugh and Polvani, 2000). The PV intrusion events are normally identified by fixing a threshold value in the range of 1-3 potential vorticity unit (PVU) (1 PVU $\left.=10^{-6} \mathrm{~km}^{2} \mathrm{~kg}^{-1} \mathrm{~s}^{-1}\right)$ at $350 \mathrm{~K}$ isentropic level $(\sim 12 \mathrm{~km}$ height). Though there is no universally accepted threshold value, some authors suggested 1.4 PVU (Manney et al., 1995), 1.5 PVU (Mohankumar et al., 2008) and 2.0 PVU (Waugh and Polvani, 2000) and in the present study, we keep $1.5 \mathrm{PVU}$ at $350 \mathrm{~K}$ as a threshold to identify the intrusion.

\subsection{MLS-UTRH data}

The Aura Microwave Limb Sounder (MLS) onboard Earth Observing System (EOS) satellite was launched on 15 July 2004. It is sun-synchronous with an altitude of $705 \mathrm{~km}$ and with a $98^{\circ}$ inclination. ML2RHI is the EOS-MLS standard product for relative humidity with respect to ice derived from radiances measured by the 118 and $190 \mathrm{GHz}$ radiometers. The current version is 3.3. The spatial coverage is nearglobal $\left(-82\right.$ to $+82^{\circ}$ latitude), with each profile spaced $1.5^{\circ}$ or $\sim 165 \mathrm{~km}$ along the orbit track (roughly 15 orbits per day). The recommended useful vertical range is from 316 to $0.0215 \mathrm{hPa}$ and the vertical resolution is between 3 and $6 \mathrm{~km}$. The MLS can observe through the cirrus clouds and this is the advantage of MLS over other instruments. It is more sensitive at $12 \mathrm{~km}$ over low latitudes (Hu and Liu, 1998).

\subsection{Gadanki radiosonde observations}

Global positioning system (GPS) radiosonde balloons have been launched daily at Gadanki since April 2006 at 12:00 UT (17:30 LT). The atmospheric parameters, namely, temperature, pressure, $\mathrm{RH}$, and horizontal winds are obtained with a height resolution of $5 \mathrm{~m}$ from surface to about $30 \mathrm{~km}$. In the present paper, the parameters averaged for $100 \mathrm{~m}$ are used for the analysis. The temperature, horizontal winds, and relative humidity are measured with an accuracy of $0.5 \mathrm{~K}, 0.5 \mathrm{~m} \mathrm{~s}^{-1}$, and $5 \%$ respectively (Nath et al., 2013).

\subsection{Outgoing Longwave Radiation (OLR)}

For the present study OLR data are taken from National Oceanic and Atmospheric Administration-National Centres for Environmental Prediction (NOAA-NCEP). The data are interpolated in time and space from NOAA twice daily OLR values and averaged to once daily. The data obtained from polar orbiting environmental satellite NOAA-16 (equatorial crossing time - 13:50) from March 2001 onwards and which is replaced by NOAA-18 (equatorial crossing time - 13:55) in September 2005. The data sets are available in $2.5^{\circ} \times 2.5^{\circ}$ latitude-longitude grid since 1 June 1974 to 31 January 2013. The low OLR represents high cloud top heights and is an indicator for deep convection (Liebmann and Hartmann, 1982). For the present study OLR $<220 \mathrm{hPa}$ is taken as threshold for identifying convection (Wild and Roeckner, 2006).

\section{Results}

The longitude-time cross sections of $\mathrm{PV}$ at $350 \mathrm{~K}$ isentropic level over $13.5^{\circ} \mathrm{N}$ and OLR averaged over $12.5-15^{\circ} \mathrm{N}$ from 6-16 March, 5-15 May for the year 2009 and from 28 April6 May and 4-14 February for the years 2010 and 2012 respectively are shown in Fig. 1. The occurrence of PV intrusion events can be inferred on 9 March and 8 May in the year 2009 and on 29 April and 7 February in the years 2010 and 


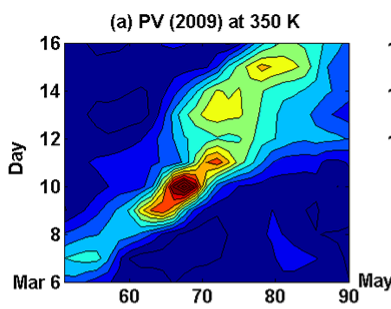

(b) PV (2009) at $350 \mathrm{~K}$

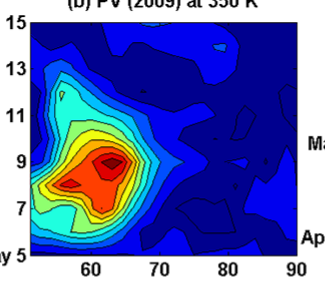

(f) OLR (2009)
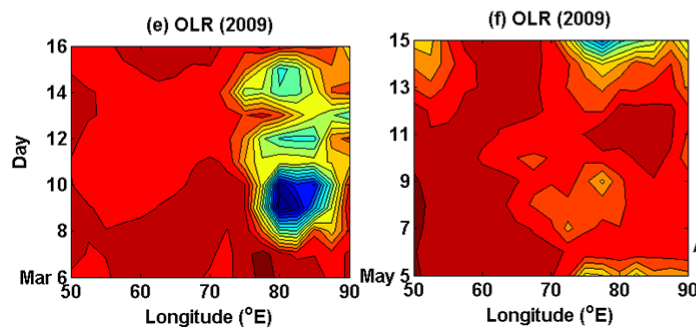

(c) PV (2010) at $350 \mathrm{~K}$

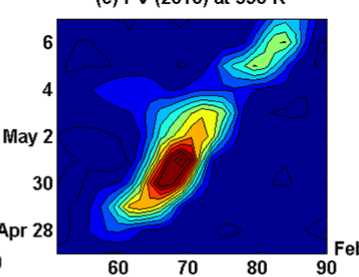

(g) OLR (2010)

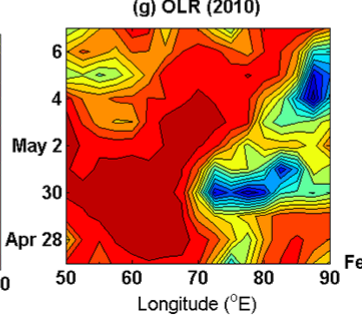

(d) PV (2012) at $350 \mathrm{~K} \quad \mathrm{PVU}$

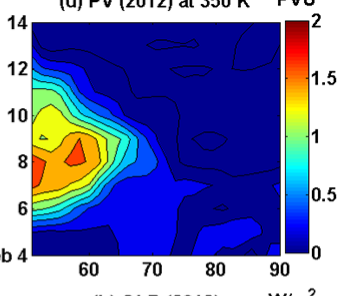

(h) OLR (2012) $\quad \mathrm{W} / \mathrm{m}^{2}$

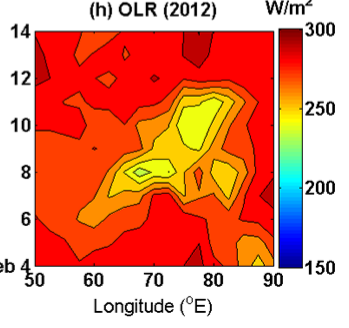

Figure 1. Longitude-time cross sections of $\mathrm{PV}$ at $350 \mathrm{~K}$ isentropic level at $13.5^{\circ} \mathrm{N}$ and OLR averaged over $12.5-15^{\circ} \mathrm{N}$ for the years 2009 , 2010 and 2012.

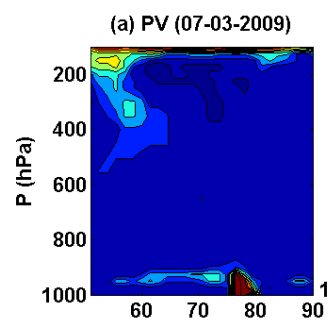

(b) PV (08-03-2009)
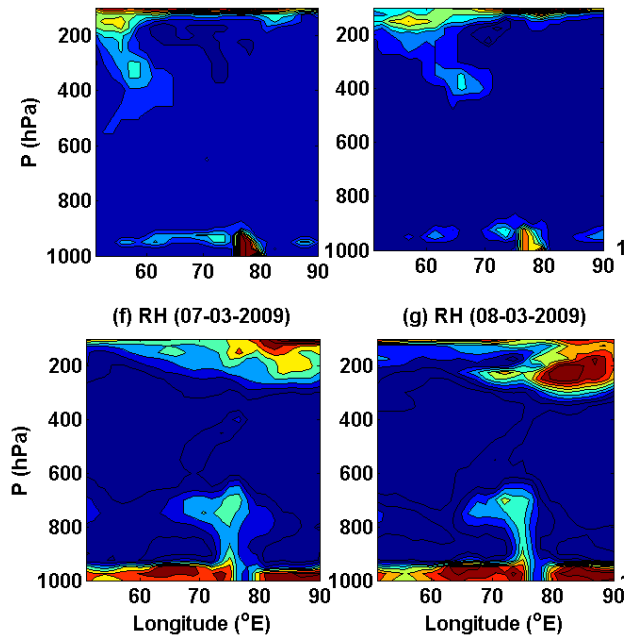

(g) RH (08-03-2009)

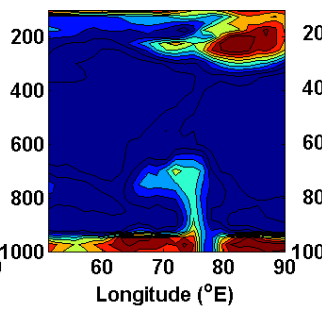

(c) PV (09-03-2009)

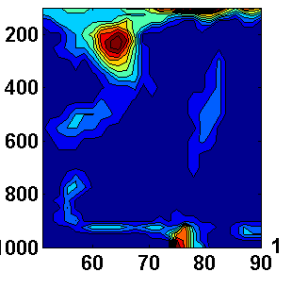

(h) RH (09-03-2009)

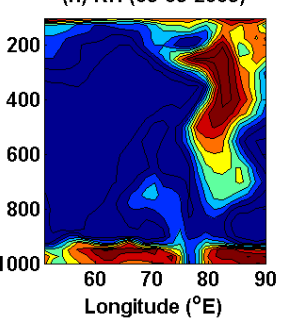

(d) PV (10-03-2009)
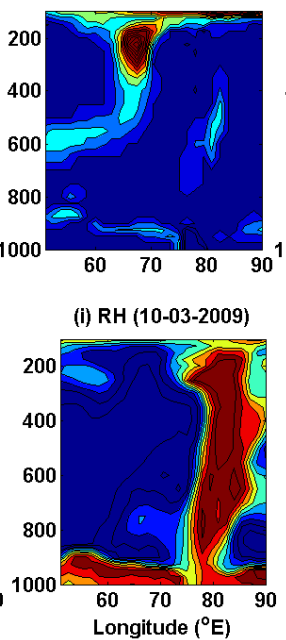

(e) PV (11-03-2009)PVU
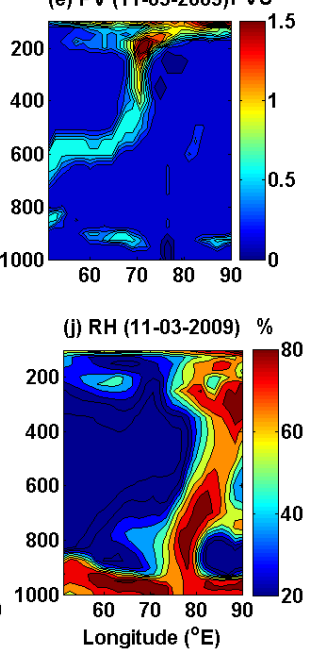

Figure 2. Longitude-height cross sections PV (a-e) and RH (f-k) at 13.5 $\mathrm{N}$ during 7-11 March 2009.

2012 respectively. The first PV event in 2009 could persist for nearly 7 days (9-15 March) spreading eastward from 60 to $80^{\circ} \mathrm{E}$, as the day progresses. The OLR shows low value $\left(<180 \mathrm{~W} \mathrm{~m}^{-2}\right)$ during the event at the east of the intrusion region from 80 to $87.5^{\circ} \mathrm{E}$ indicating that the deep convection is accompanied by the intrusion. The second event persists only for 2 days ( $8-9$ May) over 54 to $66^{\circ}$ E. However this intrusion event does not trigger convection as inferred from the high OLR ( $>260 \mathrm{~W} \mathrm{~m}^{-2}$ ). In the case of 2010 event, the PV intrusion starts on 29 April and continues till 2 May over $63-72^{\circ} \mathrm{E}$ and it triggers convection, which can be inferred from low OLR $\left(<200 \mathrm{~W} \mathrm{~m}^{-2}\right)$ over $72.5-85^{\circ} \mathrm{E}$. In the 2012 case, the intrusion lasts only for 2 days (7-9 February) over $55-66^{\circ}$ E. Though OLR is less $\left(\sim 240-250 \mathrm{~W} \mathrm{~m}^{-2}\right)$ over $65-$ $80^{\circ} \mathrm{E}$ during and after the intrusion day in case of 2012, when compared to other days, it is not low enough to consider it as deep convection.

Longitude-height cross sections of PV (a-e) and RH (fj) during 7-11 March 2009 are shown in Fig. 2. As per the threshold for identifying the PV intrusion, the event begins on 9 March 2009 (inferred from Fig. 2c). However though $\mathrm{PV}$ value does not reach the threshold to identify as intrusion event, relatively high PV (1.1 PVU) exists above $200 \mathrm{hPa}$ even on 7 March around $55^{\circ} \mathrm{E}$. The high PV layer starts to descend from $150 \mathrm{hPa}$ and reaches $350-400 \mathrm{hPa}$ on 9 and 10 March respectively. A simultaneous eastward shift to $60^{\circ} \mathrm{E}$ on 9 March and to $70^{\circ} \mathrm{E}$ on 11 March can be inferred from the Fig. 1a-d. A high RH (> 80\%) can be observed at $100 \mathrm{hPa}$ over $80-90^{\circ} \mathrm{E}$ on 7 March. The high RH layer (>90\%) over $75-90^{\circ} \mathrm{E}$ descends further down to $250 \mathrm{hPa}$ on $8 \mathrm{March}$ 

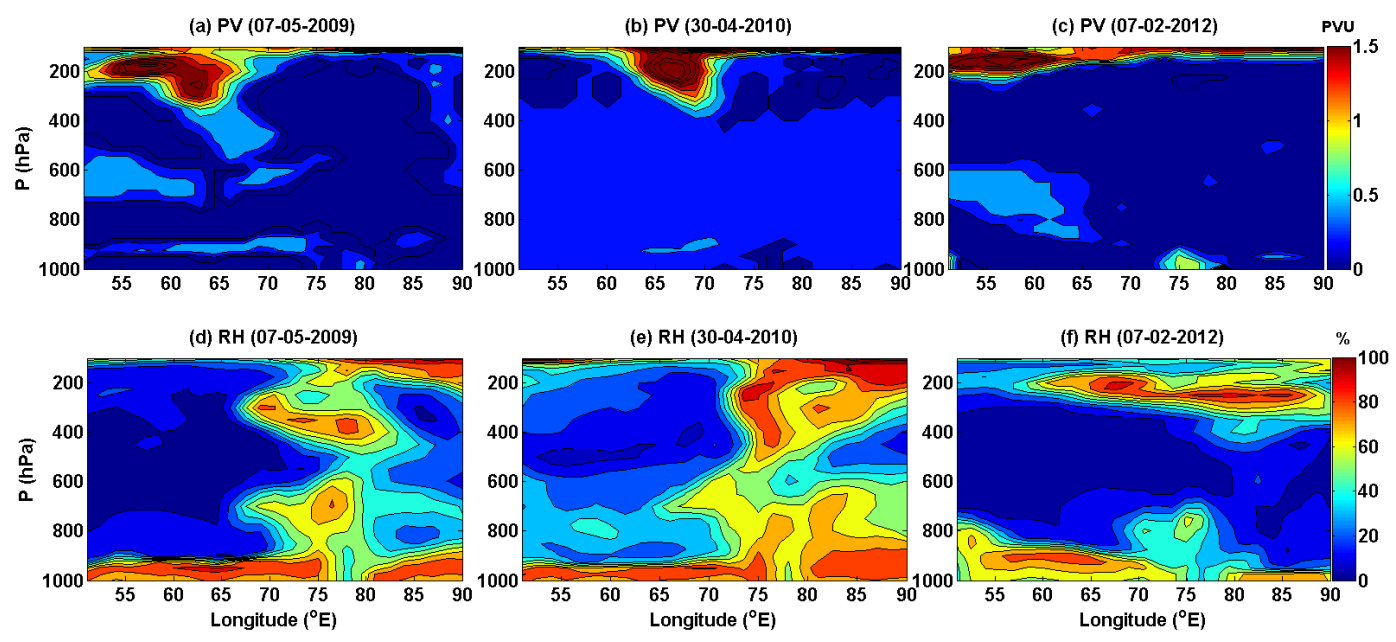

Figure 3. Longitude-height cross sections of PV (a-c) and RH (d-f) at 13.5 $\mathrm{N}$ for the days 7 May 2009, 30 April 2010 and 7 February 2012.

(a) RH (2009)
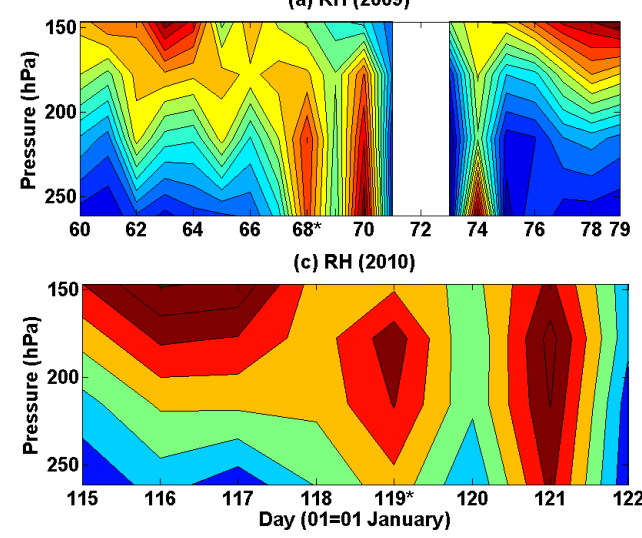

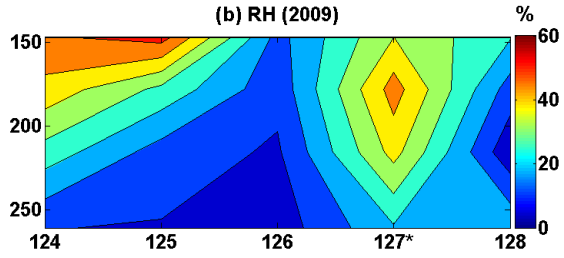

(d) RH (2012)

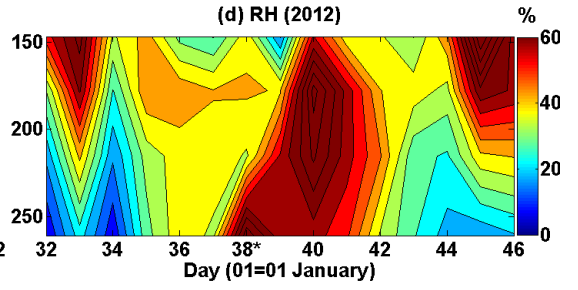

Figure 4. Time-height variation of MLS RH averaged over $10-17^{\circ} \mathrm{N}$ and $60-90^{\circ} \mathrm{E}$ for 2009,2010 and 2012 cases.

2009, to $600 \mathrm{hPa}$ on 9 March 2009 and even descends further down to surface level on 10-11 March 2009.

Longitude-height cross sections of PV (a-c) and RH (df) for the days 7 May 2009, 30 April 2010 and 7 February 2012 are shown in Fig. 3. The PV intrusion event can be inferred from the descent of high PV greater than 1.5 PVU, reaches at $300 \mathrm{hPa}$, over $50-65^{\circ} \mathrm{E}$ on 7 May 2009 and over $65-70^{\circ}$ E on 30 April 2010. However on 7 February 2012 the PV tongue reaches only $200 \mathrm{hPa}$ over $50-65^{\circ} \mathrm{E}$. Associated with these three PV intrusion events, high RH (> 80\%) can be observed to descend to $400 \mathrm{hPa}$ over $65-80^{\circ} \mathrm{E}$ on 7 May 2009 and to $450 \mathrm{hPa}$ over $70-85^{\circ} \mathrm{E}$ on 30 April 2010. However on 7 February 2012, the high RH descends to only $250 \mathrm{hPa}$ over $60-87.5^{\circ} \mathrm{E}$ consistent with less descent of $\mathrm{PV}$ tongue on that day. Though high $\mathrm{RH}(<70 \%)$ is present at lower level from surface to $600 \mathrm{hPa}$ over $75-80^{\circ} \mathrm{E}$ on both days 7 May 2009 and 30 April 2010, the RH value is 80$100 \%$ from $200-400 \mathrm{hPa}$, which does not seem to be due to low-level convection. The PV anomaly can also be origi- nated by the diabatic processes, such as condensation in and near the frontal cloud bands through convection. These PV anomalies are generated by the momentum conserving advection in a baroclinic environment in the mid troposphere (Holt and Thorpe, 1991). In such cases, PV anomalies are present exactly where the convection prevails. However in the present study, high-humidity regions are shifted to 10 $20^{\circ} \mathrm{N}$ from the upper level PV anomaly and PV anomaly is observed at upper troposphere around $200 \mathrm{hPa}$. In addition to the ERA data sets, we used MLS RH with respect to ice data to check the UTRH variations for the above-mentioned cases, as it is a standard MLS product. Figure 4 shows time-height variation of MLS RH averaged over $10-17^{\circ} \mathrm{N}$ and $60-90^{\circ} \mathrm{E}$ for the 2009, 2010 and 2012 cases. The day of intrusion is marked with an asterisk symbol in the $x$ axis labels. The value of RH with respect to ice within 200-250 hPa shows high values on the intrusion days 9-11 March 2009 (> 50\%), 7 May 2009 (> 50\%), 29 April-1 May 2010 (> 60\%) and 7-9 February 2012 (> $60 \%)$. Bock et al. (2013) noted good agree- 

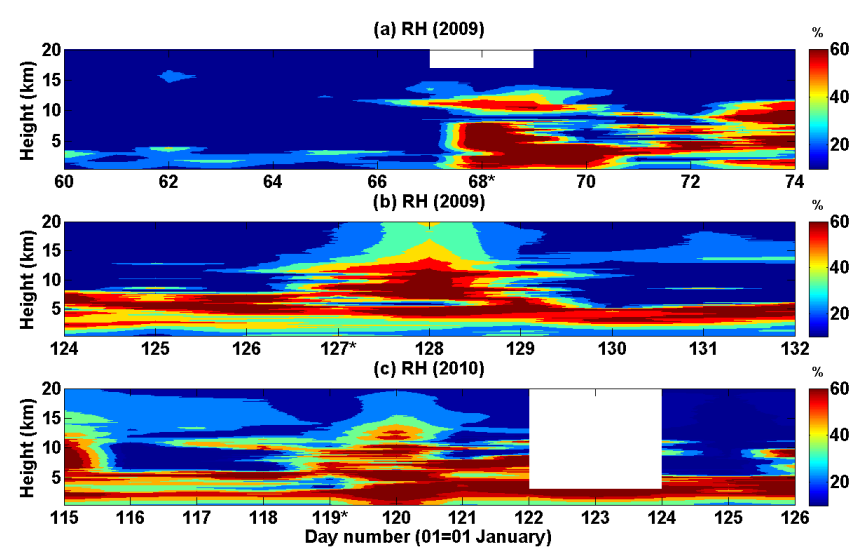

Figure 5. Time-height variation of RH obtained from the radiosonde measurements at Gadanki station $\left(13.5^{\circ} \mathrm{N}, 79.2^{\circ} \mathrm{E}\right)$ for the 2009 and 2010 cases.

ment in radiosonde humidity measurement with humidity obtained using Raman lidar and GPS technique up to $12 \mathrm{~km}$. Figure 5 shows time-height variation of RH obtained from the radiosonde measurements at Gadanki $\left(13.5^{\circ} \mathrm{N}, 79.2^{\circ} \mathrm{E}\right)$ for the two cases in 2009 and one case in 2010. However, radiosonde data are not available for the 2012 case. In all the other three cases, $\mathrm{RH}$ higher than $50 \%$ is observed during the PV intrusion days at $11-12 \mathrm{~km}$ height region.

Kiladis (1998) suggested poleward advection as a potential mechanism for high RH ahead of PV intrusions. Figure 6a-d shows longitude-latitude cross sections of PV and wind vector at $350 \mathrm{~K}$ isentropic level for 9 March 2009, 7 May 2009, 30 April 2010 and 7 February 2012. In all the cases, wind is from low to higher latitudes at the east of the intrusion and these northward winds might have transported the humid air from low to high latitudes.

To confirm the low-latitude origin of high humidity at upper troposphere, the latitude-height cross section of RH averaged over the longitudes, where humidity is high for each case is investigated for all the four cases presented. Figure 7 shows latitude-height cross section of RH for 7-12 March 2009. On 7-9 March, the presence of high RH at $0-10^{\circ} \mathrm{N}$ can be inferred from the figure. On 8 March 2009 a tongue of high RH (>80\%) extends to $16.5^{\circ} \mathrm{N}$ at $200-250 \mathrm{hPa}$, whereas the lower height levels remain dry $(\mathrm{RH}<20 \%)$. On the day of PV intrusion (9 March 2009), the high RH tongue $(>80 \%)$ at $200-250 \mathrm{hPa}$ reaches up to $27^{\circ} \mathrm{N}$ and simultaneously descends to $450 \mathrm{hPa}$ at $10-13.5^{\circ} \mathrm{N}$. On $10 \mathrm{March}$ 2009 , it descends further down to $800 \mathrm{hPa}$. On 11-12 March, the extension of high $\mathrm{RH}$ tongue at $200-250 \mathrm{hPa}$ reduces to lower latitudes and the descending structure of RH is also not present. Similarly the latitude-height cross sections of RH for other intrusion events on 7 May 2009, 30 April 2010 and 7 February 2012 are shown in Fig. 8a-c. All three cases show high $\mathrm{RH}(>80 \%)$ from surface to $100 \mathrm{hPa}$ near equator. However the extension of PV tongue at $100-200 \mathrm{hPa}$, from equator to $13.5,25,30^{\circ} \mathrm{N}$ on the respective days can be inferred from the figure. It is suggested that the poleward wind at the eastern side of intrusion trough might be the reason for the extension of RH tongue at $200 \mathrm{hPa}$.

To confirm humidity transport from equatorial region to higher latitudes at $200 \mathrm{hPa}(\sim 350 \mathrm{~K})$ one of the back trajectory models, namely, Hybrid Single Particle Lagrangian Integrated Trajectory Model (HYSPLIT) is used (see Draxler and Rolph, 2013 for details). $15^{\circ} \mathrm{N}, 75^{\circ} \mathrm{E}, 12 \mathrm{~km}$ are given as the final geographical position for the days 9 March 2009 and 30 April 2010 and $15^{\circ} \mathrm{N}, 80^{\circ} \mathrm{E}, 12 \mathrm{~km}$ for the days 7 May 2009 and 7 February 2012. The $48 \mathrm{~h}$ back trajectory is calculated with new trajectory created for every $3 \mathrm{~h}$ and the result is shown in Fig. 9a-d. It can be inferred from the figure that the air parcel comes from around $5^{\circ} \mathrm{N}$ and from the average height of $10 \mathrm{~km}$ on 9 March 2009, $12.5 \mathrm{~km}$ on 7 May 2009, $12 \mathrm{~km}$ on 30 April 2010 and $13 \mathrm{~km}$ on 7 February 2012.

The Meteosat IR imagery obtained from the website www. sat.dundee.ac.uk for these four cases of intrusion shows high moisture to the east of intrusion, with convective plume-like structure on 9 March 2009 (Fig. 10a) and 30 April 2010 (Fig. 10c) when PV intrusion triggers convection and poleward motion ahead of intrusion. However for the other two cases (Fig. 10b, d) though PV intrusion does not trigger convection, moisture transport from low to high latitudes is clearly visible.

\section{Discussion and conclusions}

Four cases are presented (two cases during the year 2009 and one each during the years 2010 and 2012) in this study to demonstrate the relationship between PV intrusion and UTRH variations over tropics. In the presented cases, only two PV intrusion events are accompanied by deep convection at the east. However, in all these cases, the ERA-interim RH data show consistent enhancements by more than $50 \%$ in the upper troposphere (200-250 hPa) over tropics at the eastward side of the intrusion region. The humidity variations in the upper troposphere depend on the strength and vertical penetration of PV to low-latitude tropical troposphere. In particular, in the 2009 case, the vertical descent of RH reaches up to $1000 \mathrm{hPa}$ on 10 March 2009 where descent of relatively high PV patches of air can also be inferred up to $600 \mathrm{hPa}$. However for the second event in the same year (2009) the high RH layer descends only up to $400 \mathrm{hPa}$, where the descent of $\mathrm{PV}$ is limited to $300 \mathrm{hPa}$. The increase in $\mathrm{RH}$ is confirmed with Gadanki radiosonde observations and spaceborne MLS observations.

Earlier, Sassi et al. (2001) noted that the upper tropospheric moisture was forced by deep convection. Though the major source of tropical UTRH is convection (Houze and Betts, 1981; Held and Soden, 2000; Uma et al., 2014), the moisture advection and diffusion control its large-scale distribution (Betts and Albrecht, 1987; Sun and Lindzen, 1993). 
(a) PV at $350 \mathrm{~K}$ (09-03-2009)

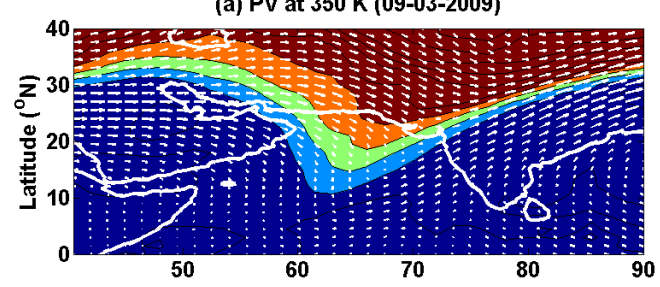

(b) PV at $350 \mathrm{~K}$ (30-04-2010)

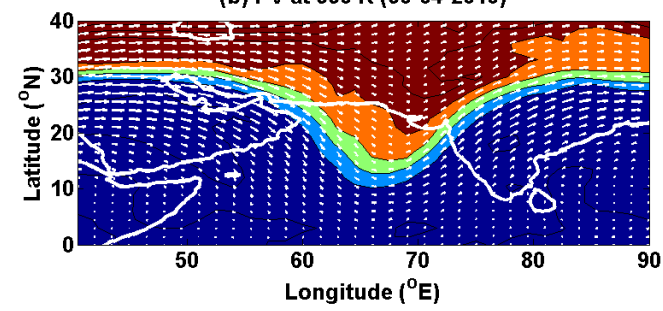

(c) PV at $350 \mathrm{~K}(07-05-2009)$

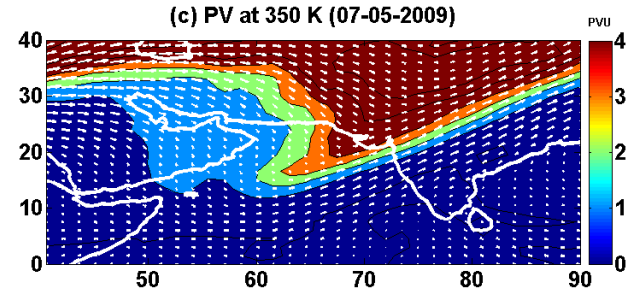

(d) PV at $350 \mathrm{~K}$ (07-02-2012)

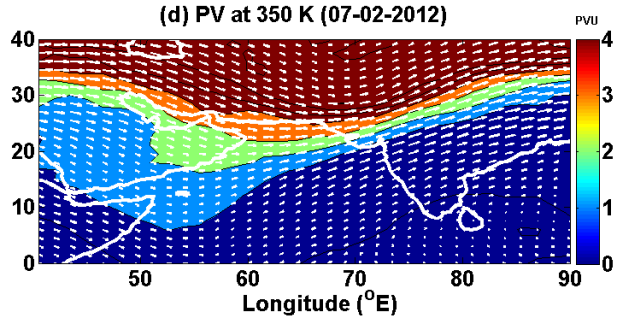

Figure 6. Longitude-latitude cross sections of PV and wind vector at $350 \mathrm{~K}$ isentropic level for (a) 9 March 2009, (b) 7 May 2009, (c) 30 April 2010 and (d) 7 February 2012.
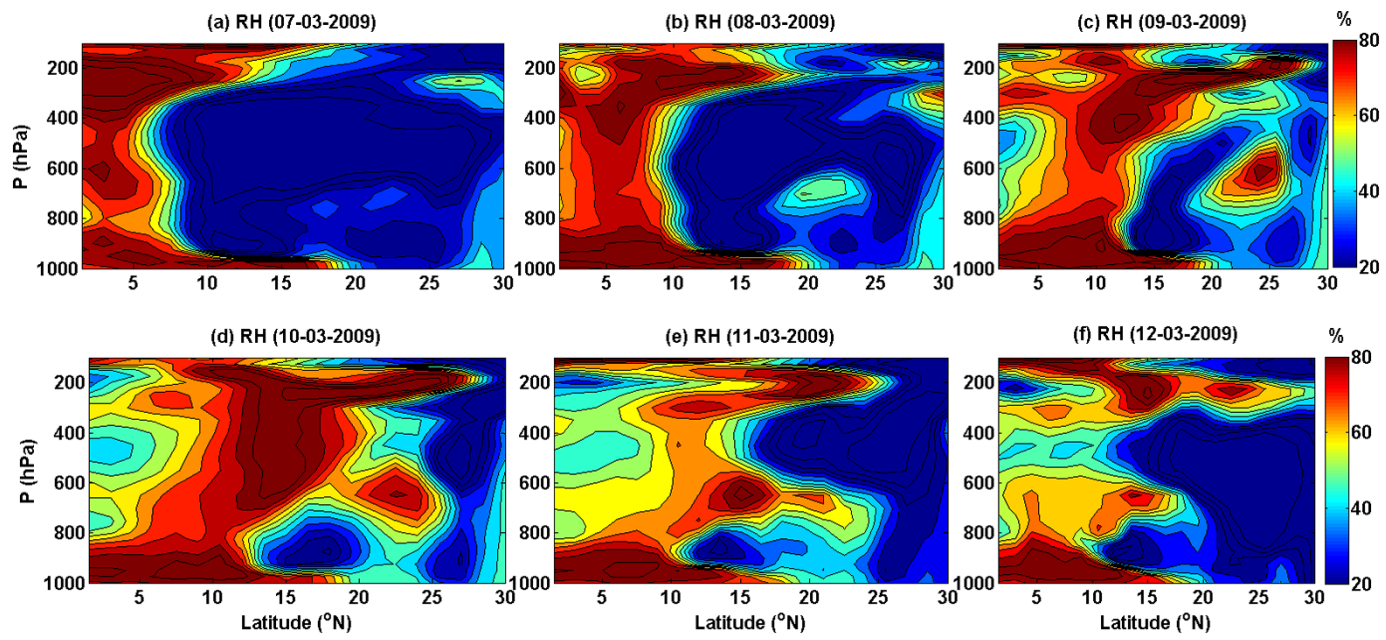

Figure 7. Latitude-height cross section of RH from 7 March to 12 March 2009.

Both convection and poleward advection are normally associated with the PV intrusion to the eastern side of intrusion (Kiladis, 1998; Funatsu and Waugh, 2008). In the present study, the region of high $\mathrm{RH}$ shifts to east from the location of PV intrusion by $10-20^{\circ}$ longitude in all the cases. However, the increase in RH occurs here irrespective of convection triggered by the $\mathrm{PV}$ intrusion. It is demonstrated that the increase in RH is due to poleward advection induced by the PV intrusions in their eastward side at upper tropospheric heights, though the convection, which is not necessarily triggered by the PV intrusion might have transported water vapour to upper tropospheric heights. Using AIRS and MLS observations, Waugh (2005) noted dry air within the intrusions and moist air east of the intrusions, as observed in the present study. However, in their observations, the deep convection was triggered by the PV intrusions. Ten year (2004-
2013) statistics of the PV intrusions (22 cases) over the Indian sector suggests that all the PV intrusions over the Indian sector $\left(50-90^{\circ} \mathrm{E}\right)$ are not associated with deep convection or precipitation. The total number of $\mathrm{PV}$ intrusions for the years $2004-2013$ at $200 \mathrm{hPa}(\sim 350 \mathrm{~K}$, isentopic level) and $13.5^{\circ} \mathrm{N}$ over $50-90^{\circ} \mathrm{E}$ and the number of intrusions among them which lead to and do not lead to precipitation are shown in Fig. 11. From the figure, we can infer that there is no PV intrusion in the years 2008 and 2013 and all the PV intrusions in the years 2006 and 2009 do not lead to precipitation. In the years 2004, 2007 and 2011, 50\% of the intrusions do not lead to precipitation and in other years, more than $50 \%$ of the cases do not lead to the precipitation. In the year 2005, the number of intrusions leading to precipitation is more. Among the total of $22 \mathrm{PV}$ intrusion events, 7 events are associated with the development of convection in the eastward 

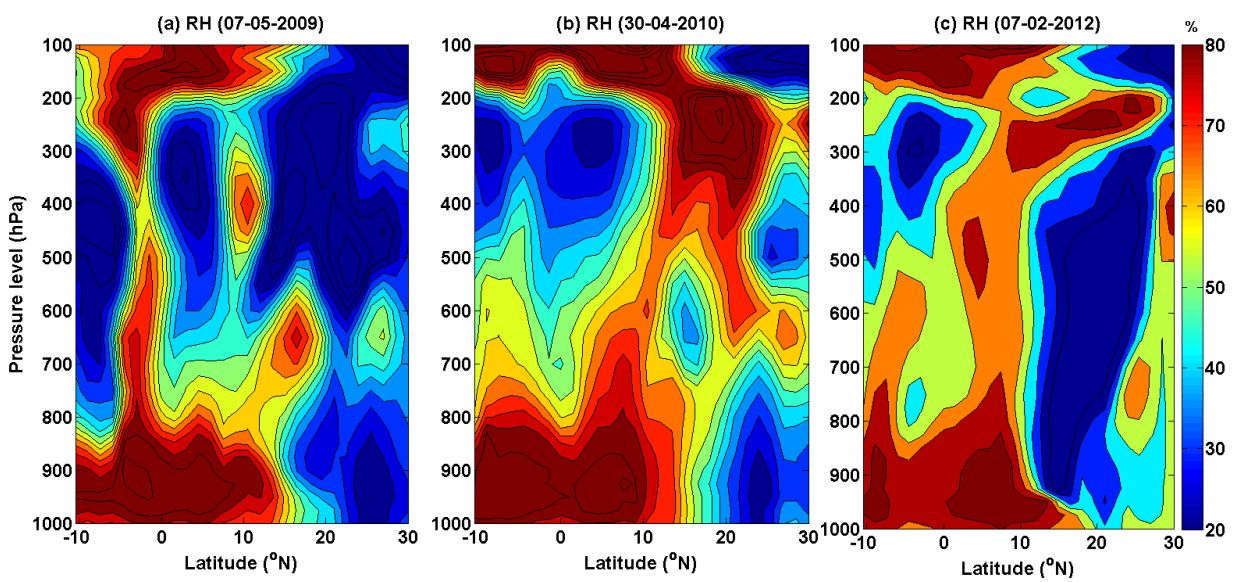

Figure 8. Latitude-height cross section of RH for the days 7 May 2009, 30 April 2010 and 7 February 2012.

(a) NOAA HYSPLIT MODEL Backward trajectories ending at 1200 UTC 09 Mar 09

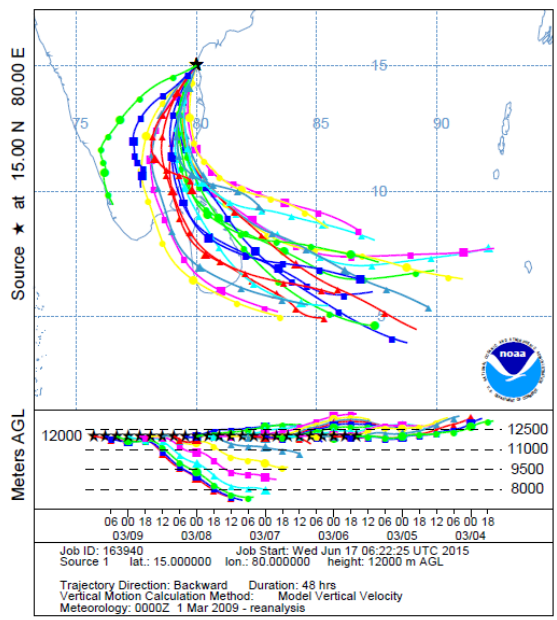

(c) NOAA HYSPLIT MODEL

Backward trajectories ending at 1200 UTC 30 Apr 10

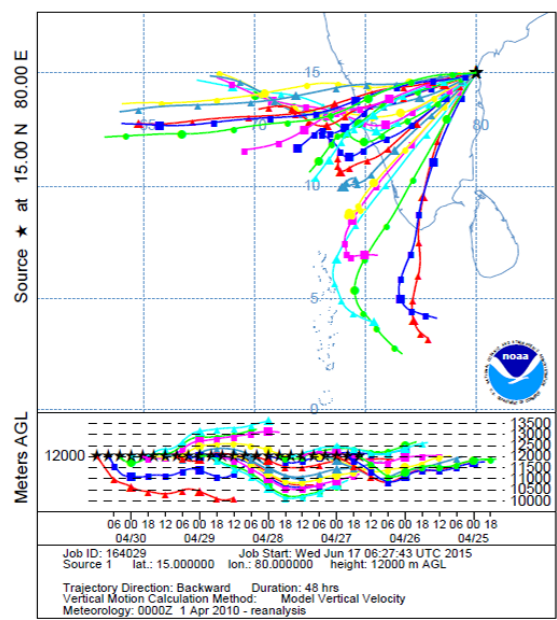

(b) NOAA HYSPLIT MODEL Backward trajectories ending at 1200 UTC 07 May 09

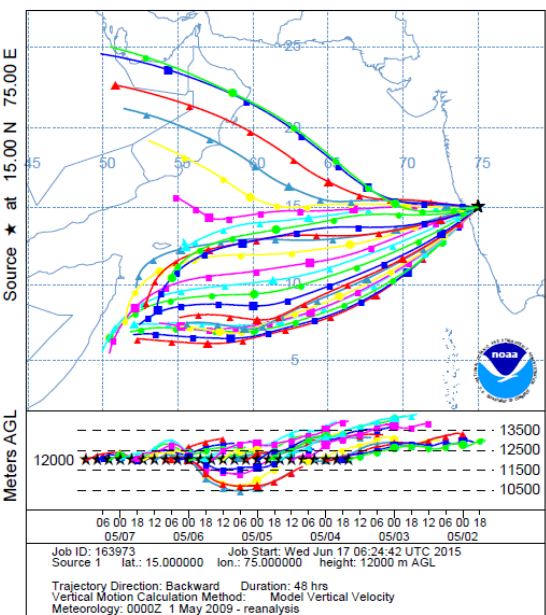

(d) NOAA HYSPLIT MODEL Backward trajectories ending at 1200 UTC 07 Feb 12

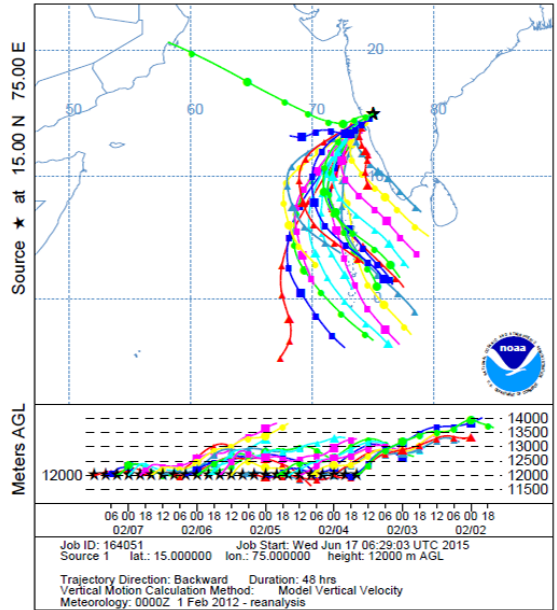

Figure 9. (a-b) $48 \mathrm{~h}$ back trajectory ending at 12:00 UT on 9 March and 7 May 2009 using National Oceanic Atmospheric Administration (NOAA) HYSPLIT model. (c-d) Same as (a)-(b) but on 30 March 2010 and 7 February 2012. 

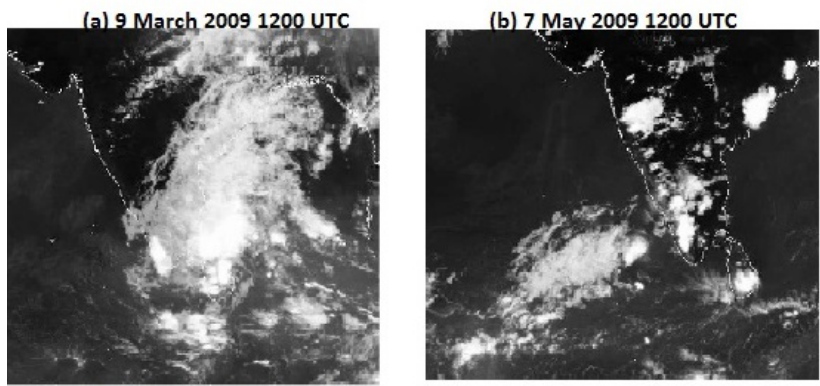

(c) 30 April 20101200 UTC
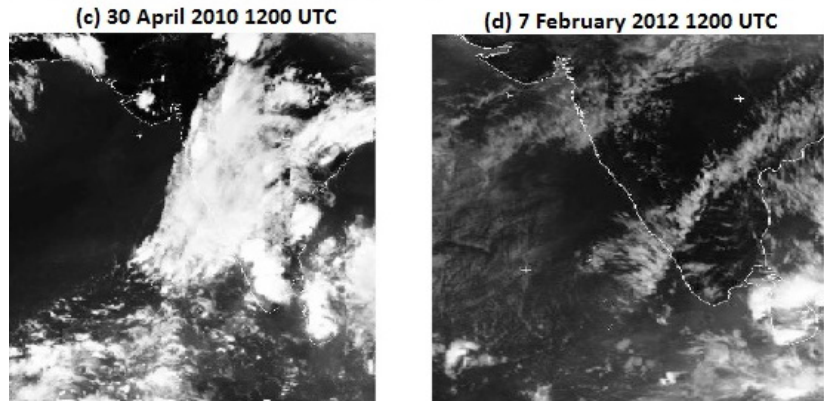

Figure 10. METEOSAT IR image on 9 March 2009, 7 May 2009, 30 April 2010 and 7 February 2012 at 12:00 UTC.

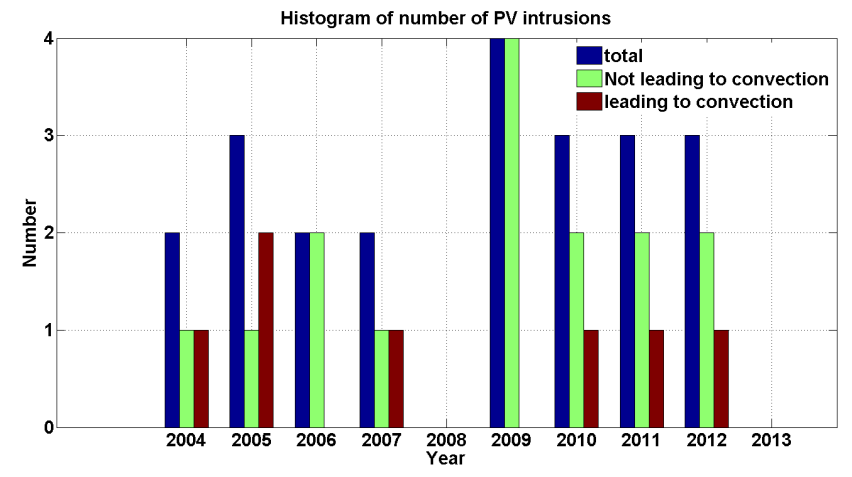

Figure 11. Histogram of total number of PV intrusions at $13.5^{\circ} \mathrm{N}$ for the years 2004-2013. Histograms of the number of intrusions leading to convection and of the number of intrusions not leading to convection are also shown for comparison.

side of the intrusions and 15 events do not lead to convection in the region eastward side as well as below the intrusion region. However, UTRH enhancements are present in all these cases. It is the northward flow associated with the PV intrusion that transports water vapour from equatorial latitudes where convection is nearly always present. The simulations by Dessler and Sherwood (2000) suggested the importance of realistic three-dimensional large-scale wind fields to accurately predict the variations of UTRH. Ryoo et al. (2008) reported poleward advection associated with the PV intrusion as a potential mechanism for the UTRH enhancement. Consistent with this, in the present study, the wind vector at $350 \mathrm{~K}$ isentropic level shows the flow from low to high latitudes to the east of the PV intrusion. The latitude-height cross section of RH also shows the spread of high RH from low to high latitudes at $200-250 \mathrm{hPa}$ first and later it descends to lower heights. The $48 \mathrm{~h}$ backward trajectory analysis confirms the transport of moist air from low latitude to high latitude at the upper troposphere for all the four presented cases.

Based on the observational evidence, the present study demonstrates the relationship between PV intrusions over the Indian sector and upper tropospheric humidity variations over tropical latitudes due mainly to poleward motion ahead of the intrusive trough.

Acknowledgements. The authors acknowledge ECMWF for ERA-interim data sets used in this study. They also thank NASA for providing MLS RHi data through the website http://mirador.gsfc.nasa.gov/. The meteosat images used in the present study are downloaded from the website http://www.sat.dundee.ac.uk/ and the back trajectories are downloaded from the website http://www.arl.noaa.gov/HYSPLIT.php. The authors would like to thank the editor and the two reviewers for their comments and suggestions.

\section{Edited by: V. Kotroni}

Reviewed by: two anonymous referees

\section{References}

Arakawa, A. and Schubert, W. H.: Interaction of a cumulus cloud ensemble with the scale environment, Int. J. Atmos. Sci., 31, 674-701, 1974.

Baray, J. L., Ancellet, G., Taupin, F. G., Bessaft, M., Baldy, M., and Keckhut, P.: Subtropical tropopause break as a possible stratospheric source of ozone in the tropical troposphere, J. Atmos. Sol.-Terr. Phy., 60, 27-36, 1998.

Berrisford, P., Dee, D., Fielding, K., Fuentes, M., Kallberg, P., Kobayashi, S., and Uppala, S.: The ERA-interim Archive, European Centre for Medium Range Weather Forecasts, Shinfield Park, Reading, Berkshire RG2 9AX, United Kingdom, 1-16, 2009.

Betts, A. K. and Albrecht, B. A.: Conserved variable analysis of the convective boundary layer thermodynamic structure over the tropical oceans, J. Atmos. Sci., 44, 83-99, 1987.

Bock, O., Bosser, P., Bourcy, T., David, L., Goutail, F., Hoareau, C., Keckhut, P., Legain, D., Pazmino, A., Pelon, J., Pipis, K., Poujol, G., Sarkissian, A., Thom, C., Tournois, G., and Tzanos, D.: Accuracy assessment of water vapour measurements from in situ and remote sensing techniques during the DEMEVAP 2011 campaign at OHP, Atmos. Meas. Tech., 6, 2777-2802, doi:10.5194/amt-6-2777-2013, 2013.

Chen, M., Rood, R. B., and Joiner, J.: Assimilating TOVS humidity into the GOES-2 Data assimilation system, J. Climate, 12, 29832995, 1999.

Danielsen, E. F.: A dehydration mechanism for the stratosphere, Geophys. Res. Lett., 9, 605-604, 1982.

De Bellevue, J. L., Rechou, J. A., Baray, J. L., Ancellet, G., and Diab, R. D.: Signatures of stratosphere to troposphere transport near deep convective events in the southern subtropics, J. Geophys. Res., 111, D24107, doi:10.1029/2005JD006947, 2006. 
Dessler, A. and Sherwood, S. C.: Simulations of tropical upper tropospheric humidity, J. Geophys. Res., 105, 20155-20163, 2000.

Draxler, R. R. and Rolph, G. D.: HYSPLIT (Hybrid Single-Particle Lagrangian Integrated Trajectory) Model access via NOAA ARL READY Website (http://www.arl.noaa.gov/HYSPLIT. php), NOAA Air Resources Laboratory, College Park, MD, 2013.

Folkins, I. and Appenzeller, C.: Ozone and potential vorticity at the subtropical tropopause break, Geophys. Res. Lett., 101, 1878718792, 1996.

Funatsu, B. M. and Waugh, D. W.: Connections between potential vorticity intrusions and convection in the eastern tropical Pacific, J. Atmos. Sci., 65, 987-1002, 2008.

Gettelman, A., Collins, W. D., Fetzer, E. J., Eldering, A., Irion, F. W., Duffy, P. B., and Bala, G.: Climatology of UpperTropospheric Relative Humidity from the Atmospheric Infrared Sounder and Implications for Climate, J. Climate, 19, 61046121, 2006.

Hansen, J., Lacis, A., Rind, D., Russell, G., Stone, P., Fung, I., Ruedy, R., and Learner, J.: Climate sensitivity: Analysis of feedback mechanisms, in: Climate processes and climate sensitivity, edited by: Hansen, J. E. and Takahashi, T., Geophys. Monger. Ser., 29, 130-163, AGU, Washington, D.C., 1984.

Held, I. M. and Soden, B. J.: Water vapour feedback and global warming, Ann. Rev. Energy. Env., 25, 441-475, 2000.

Holt, M. W. and Thorpe, A. J.: Localized forcing of slantwise motion at fronts, Q. J. Roy. Meteorol. Soc., 117, 943-963, 1991.

Houze Jr., R. A. and Betts, A. K.: Convection in GATE, Rev. Geophys., 19, 541-576, 1981.

$\mathrm{Hu}, \mathrm{H}$. and Liu, W. T.: The impact of upper tropospheric humidity from microwave limb sounder on midlatitude greenhouse effect, Geophys. Res. Lett., 25, 3151-3154, 1998.

Inamdar, A. K. and Ramanathan, V.: Physics of the greenhouse effect and convection in warm oceans, J. Climate, 7, 715-731, 1994.

Jones, R. L. and Mitchell, J. F. B.: Is water vapour understood?, Nature, 353, 210, 1991.

Kentarchos, A. S., Davies, T. D., and Zerefos, C. S. A.: Low latitude stratospheric intrusion associated with a cut-offlow, Geophys. Res. Lett., 25, 67-70, 1998.

Kiladis, G. N.: Observations of Rossby waves linked to convection over the eastern tropical Pacific, J. Atmos. Sci., 55, 321-339, 1998.

Liao, X. and Rind, D.: Local upper tropospheric/lower stratospheric clear-sky water vapor and tropospheric deep convection, J. Geophys. Res., 102, 19543-19557, doi:10.1029/97JD01258, 1997.

Liebmann, B. and Hartmann, D. L.: Interannual variations of outgoing IR associated with tropical circulation changes during 197478, J. Atmos. Sci., 39, 1153-1162, 1982.

Lindzen, R. S.: Some coolness concerning global warming, B. Am. Meteorol. Soc., 71, 288-299, 1990.

Manney, G. L., Zurek, R. W., Froidevaux, L., Waters, J. W., Neill, A. O., and Swinbank, R.: Lagrangian transport calculations using UARS Data. Part II: Ozone, J. Atmos. Sci., 52, 3069-3081, 1995.

Mohankumar, K.: Stratosphere Troposphere Interactions - An Introduction, Springer, 416 pp., 2008.
Nath, D., Sridharan, S., Sathishkumar, S., Gurubaran, S., and Chen, W.: Lower stratospheric gravity wave activity over Gadanki $\left(13.5^{\circ} \mathrm{N}, 79.2^{\circ} \mathrm{E}\right)$ during the stratospheric sudden warming of 2009: Link with potential vorticity intrusion near Indian sector, J. Atmos. Sol.-Terr. Phy., 94, 54-64, 2013.

Newell, R. E. and Gloud-Stewart, S.: A stratospheric fountain, J. Atmos. Sci., 38, 2789-2796, 1981.

Panwar, V., Jain, A. R., Goel, A., Mandal, T. K., Rao, V. R., and Dhaka, S. K.: Some features of water vapor mixing ratio in tropical upper troposphere and lower stratosphere: Role of convection, Atmos. Res., 108, 86-103, 2012.

Rind, D., Chiou, E. W., Chu, W., Larsen, J., Oltmans, S., Lerner, J., McCormick, M. P., and McMaster, L.: Positive water vapour feedback in climate models confirmed by satellite data, Nature, 349, 500-503, 1991.

Rind, D., Chiou, E.-W., Chu, W., Oltmans, S., Lerner, J., Larsen, J., McCormick, M. P., and McMaster, L.: Overview of the Stratospheric Aerosol and Gas Experiment II water vapor observations - Method, validation, and data characteristics, J. Geophys. Res., 98, 4835-4856, 1993.

Ryoo, J.-M., Waugh, D. W., and Gettelman, A.: Variability of subtropical upper tropospheric humidity, Atmos. Chem. Phys., 8, 2643-2655, doi:10.5194/acp-8-2643-2008, 2008.

Sandhya, M. and Sridharan, S.: Observational relations between potential vorticity intrusions and premonsoon rainfall over Indian sector, Atmos. Res., 137, 80-90, 2014.

Sassi, F., Salby, M., Pumphrey, H. C., and Read, W. G.: Influence of the Madden-Julain Oscillation on upper tropospheric humidity, J. Geophys. Res., 107, 4681, doi:10.1029/2001JD001331, 2001.

Shine, K. P. and Sinha, A.: Sensitivity of the Earth's climate to height dependent changes in water vapour mixing ratio, Nature, 354, 382-284, 1991.

Soden, B. J. and Bretherton, F. P.: Upper-tropospheric relativehumidity from the GOES $6.7 \mu \mathrm{m}$ channel Method and climatology for July 1987, J. Geophys. Res., 98, 16669-16688, 1993.

Soden, B. J. and Fu, R.: A satellite analysis of deep convection, upper tropospheric humidity and greenhouse effect, J. Climate, 8, 2335-2351, 1995.

Sun, D. Z. and Lindzen, R. S.: Distribution of tropical tropospheric water vapour, J. Atmos. Sci., 50, 1644-1660, 1993.

Udelhofen, P. M. and Hartmann, D. L.: Influence of tropical cloud systems on relative humidity of the upper troposphere, J. Geophy. Res., 100, 7423-7440, 1995.

Uma, K. N., Das, S. K., and Das, S. K.: A climatological perspective of water vapour at the UTLS region over different global monsoon regions: Observations inferred from the Aura-MLS and reanalysis data, Clim. Dynam., 43, 1-2, 407-520, 2014.

Waugh, D. W.: Impact of potential vorticity intrusions on subtropical upper tropospheric humidity, J. Geophys. Res., 110, doi:10.1029/2004JD005664, 2005.

Waugh, D. W. and Polvani, L. M.: Intrusions into tropical upper troposphere, Geophys. Res. Lett., 27, 3857-3860, 2000.

Wild, M. and Roeckner, E.: Radiative fluxes in the ECHAM5 general circulation model, J. Climate, 19, 3792-3809, doi:10.1175/JCLI3823.1, 2006. 